Draft, not to be quoted without permission of the author!

\title{
The impact of the EU-MERCOSUR deal on Africa in times of resurging protectionism
}

\author{
Dirk Kohnert ${ }^{1}$
}
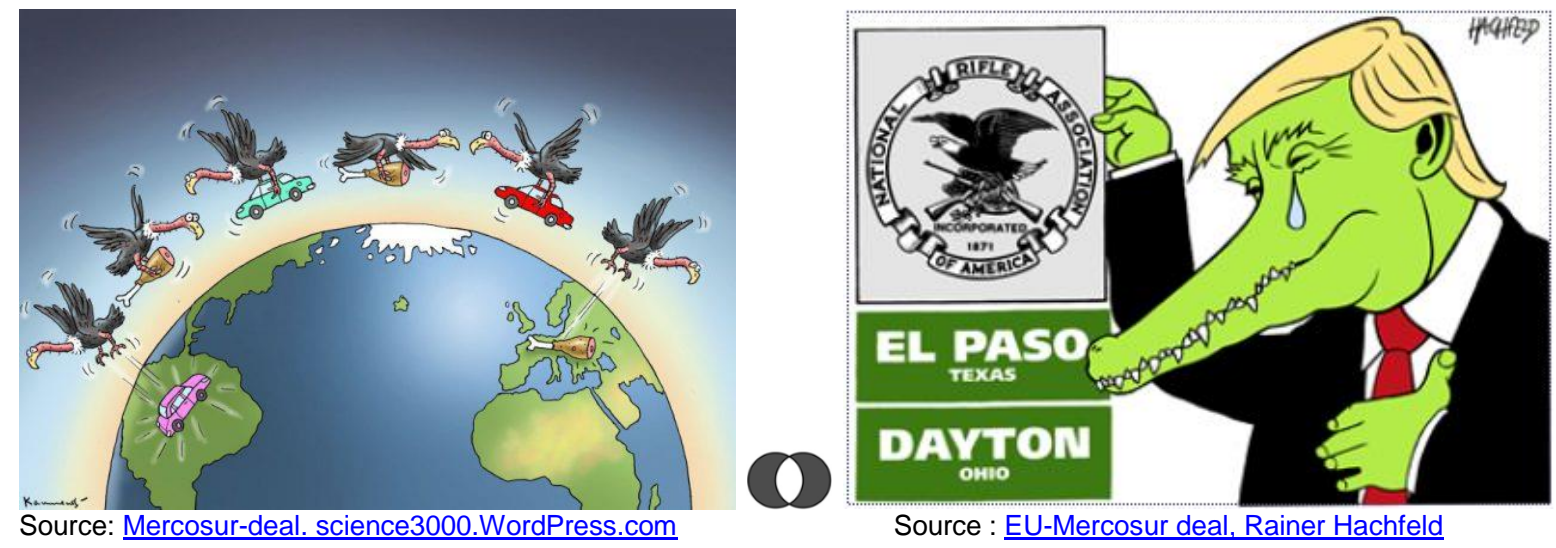

\begin{abstract}
The EU-Mercosur deal of 2019 was heralded as a milestone of free trade agreements worldwide in times of growing protectionism and nationalism. Critics condemned deficient ecological and sanitary standards as well as persistent non-tariff barriers to trade. The EU farm lobby complained about a sell-out of European interests in advantage of dominating multinationals. However, the fatal repercussions of the deal on Africa have rarely been mentioned. They include increasing cut-throat competition and asymmetrical partnership to the detriment of the African poor. Given the additional destructive impact of the Brexit crisis, African governments should use their increased bargaining power vis à vis the EU27 and the UK, in times of stiffening competition concerning the EU's Africa trade with new global players such as China and India, to enforce EPAs re-negotiation on a level playing field.
\end{abstract}

Keywords: EU, MERCOSUR, Africa, post-colonialism, development, international trade, ODA, Brexit, security, partnership, multinationals

JEL-Codes: E26, F13, F15, F23, F35, F42, F54, N46, N47, O17, Z13

\footnotetext{
${ }^{1}$ Associated research fellow, Institute of African Affairs, German Inst. of Global and Area Studies, Hamburg. Revised: 9 September 2019.
} 
Draft, not to be quoted without permission of the author!

\section{Introduction}

When the EU-Mercosur deal was finally signed on 28 June 2019 on the G-20 summit in Osaka (Japan) after two decades of negotiations it was heralded as a milestone of free trade agreements in times of growing protectionism and nationalism. It is the largest EU-trade deal so far which involves a population of $773 \mathrm{~m}$ inhabitants in the common trading area as well as around 60,500 European companies and 855,000 jobs in Europe and another 436,000 in Brazil. (EC, 2019c) Trade between the EU and Mercosur presently amounts to $€ 88$ billion and $€ 34$ billion annually in goods and services respectively (Bertolini, 2019). Expected economies in tariffs are estimated at over $€ 4$ billion when tariffs will be phased out for $91 \%$ of European goods exported to Mercosur and for $92 \%$ of Mercosur goods imported to Europe.

\section{Graph 1: EU-Mercosur deal, key facts}
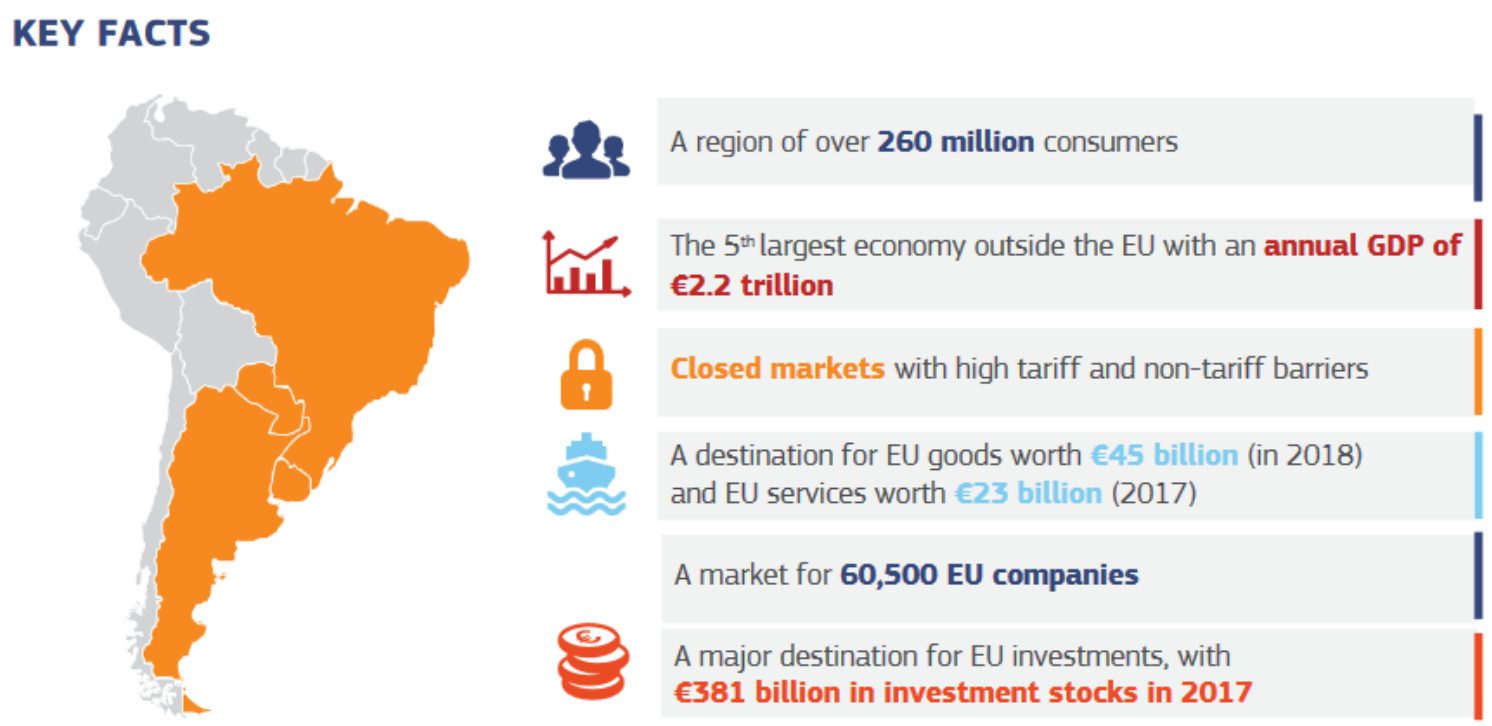

Source: EC, 2019c

As for the EU, industry and agriculture are arguably benefiting mostly by the scrapping of tariffs that for example presently still amount to $35 \%$ for exported cars, $27 \%$ for wine and 28 $\%$ for dairy products. To protect European farmers, the liberalisation will be phased out for the most sensitive products in a seven-year transition period. Moreover, the deal comprises more than trade liberalization. The EU will benefit also from facilitated procedures and privileged access to public procurement in the Mercosur market, thus giving it a competitive advantage over the rest of the world. Last, but not least, the agreement deals with sustainable development and protection of the environment and provides for elevated labour, environmental- and climate protection standards (Bertolini, 2019).

Yet, the deal remains controversial because of concerns of European farmers and environmentalists who are afraid of unfair competition and softening sanitary and ecological standards. Besides, the deal will come into effect soonest in 2021, because it still has to be ratified in parliament by all Mercosur and EU member states as well as by the European Parliament and EU Council, a complicated process in view of persisting political controversies, notably within the EU (EIU, 2019; Brundsen et al 2019). France, Ireland and Luxembourg had announced already their intention to reject the agreement in its present form. The German Federal Government recently expressed scepticism as well, among other things, because of the lack of sanctions, for example concerning the burning down of the rainforest in the Amazon (Bonse, 2019). 
Draft, not to be quoted without permission of the author!

As for Latin America, the deal promised a bright future concerning a free-trade-zone that hitherto had been portrayed rather as a fair-weather arrangement, characterized by beggarthy-neighbour nationalism, protected by safeguards, anti-dumping measures and countervailing duties. In short, it was branded as "ceremonial regionalism" and a "golden straightjacket" rather than a common market (Margolis, 2019). The new deal with the EU would scrap tariffs on $82 \%$ of Mercosur's agricultural products, like coffee, fruit and orange juice, while reducing tariffs for other products, including citrus, berries and some vegetables, gradually to zero over a four to ten-year period and raise tariff-free quotas on beef, sugar and ethanol over a decade (Maxwell, 2019). In general, it promised a boost to Mercosur member's informal economies and underperforming industries. Last, but not least, it constituted a welcomed political backing for right-wing Brazilian President Jair Bolsonaro who apparently forgot about his protectionist economic policies in view of the alluring profits promised by the EU-Mercosur deal, just like Uruguay's socialist President Tabaré Vázquez, who preferred pragmatism instead of dogmatic anti-capitalist rhetoric, and Argentina's President Mauricio Macri, who was pleased that his market-friendly reform agenda had been honoured by the deal, which would enhance his chances of re-election in times of a lowperforming economy and high inflation (Margolis, 2019).

The Mercosur was established in 1991 and encompasses Argentina, Brazil, Paraguay and Uruguay. A fifth member, Venezuela, which officially joined in July 2012 , was suspended from membership in 2017. Bolivia is a candidate member and another six countries are associated: $\underline{\text { Chile, }}$ Colombia, Ecuador, Guyana, Peru and Suriname.

Map 1: Mercosur countries

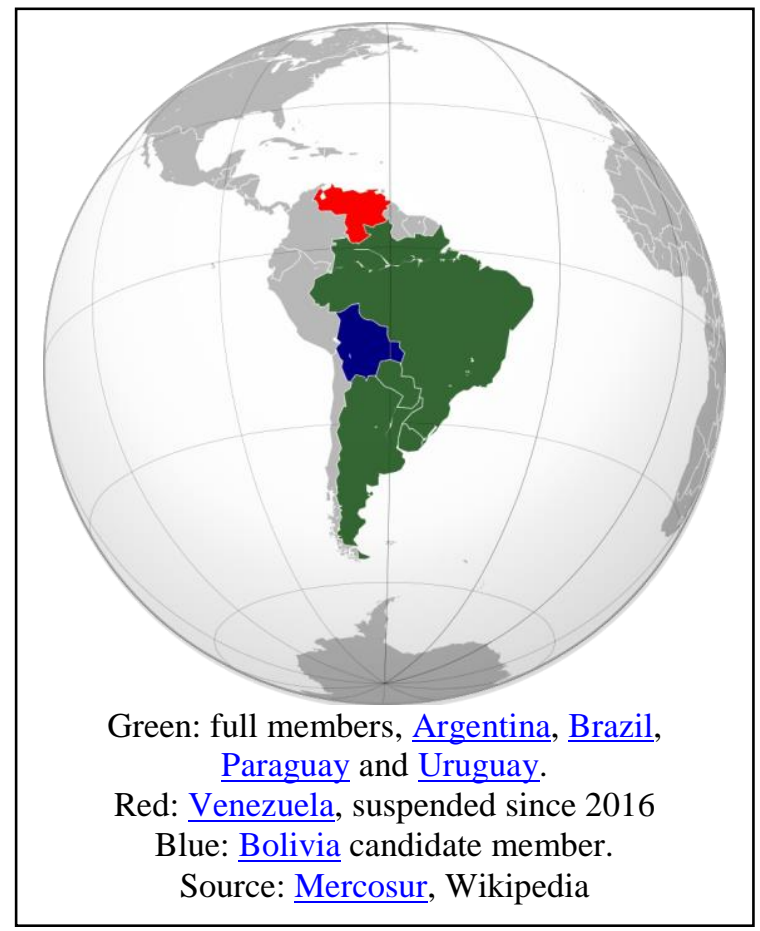

The EU has been for a long time Mercosur's number one trade and investment partner. Only in 2017, China overtook the EU as Mercosur's main trading partner. That is, currently, the EU is Mercosur's second-biggest trade in goods partner, accounting for $20.1 \%$ of the bloc's total trade in 2018. The EU on the other hand exported to the four Mercosur countries totalled $€ 45$ billion in 2018. Mercosur's exports to the EU were $€ 42.6$ billion in 2018, concentrating on agricultural products, such as foodstuffs, beverages and tobacco (20.5\%), vegetable products including soya and coffee (16.3\%) and meats and other animal products $(6.1 \%)$ (EC, 2019). Both, EU exports and imports of goods from Mercosur increased steadily from 
Draft, not to be quoted without permission of the author!

2004 to 2013 (Fig. 1). EU exports to Mercosur doubled and stood at $€ 41.6$ billion (2016). Its imports increased by about $50 \%$ and stood at $€ 40.3$ billion. In comparison, Mercosur was of similar importance to the EU as India, accounting for around $2.5 \%$ of total extra-EU28 imports and exports (LSE, 2018: 32).

Figure 1: EU goods exports and imports to/from Mercosur, $2004-2016$

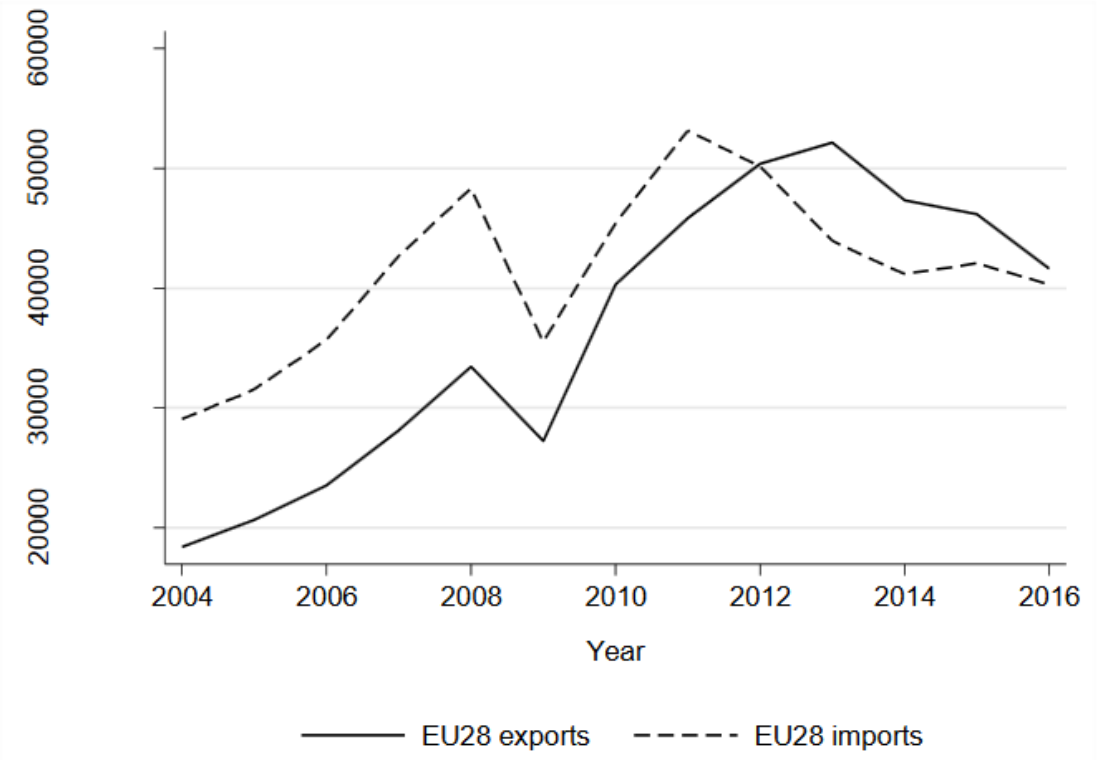

Notes: Figure shows EU exports and imports to/from Mercosur (in € millions, current prices). Source: COMEXT Source: LSE, 2018: 32

The EU mainly imports agricultural products, like food, live animals and raw materials that account for about $70 \%$ of EU imports, whereas imported manufactured products account for only $25 \%$. For EU exports to the South American trading area, the pattern is reversed, with manufactured goods, like cars and cars parts making up over $90 \%$. These trading patterns are in line with the comparative advantages of the EU and Mercosur to be expected (Schwarzbauer \& Hügel, 2019; LSE, 2018: 35-36).

Figure 2: EU service exports and imports to/from Mercosur

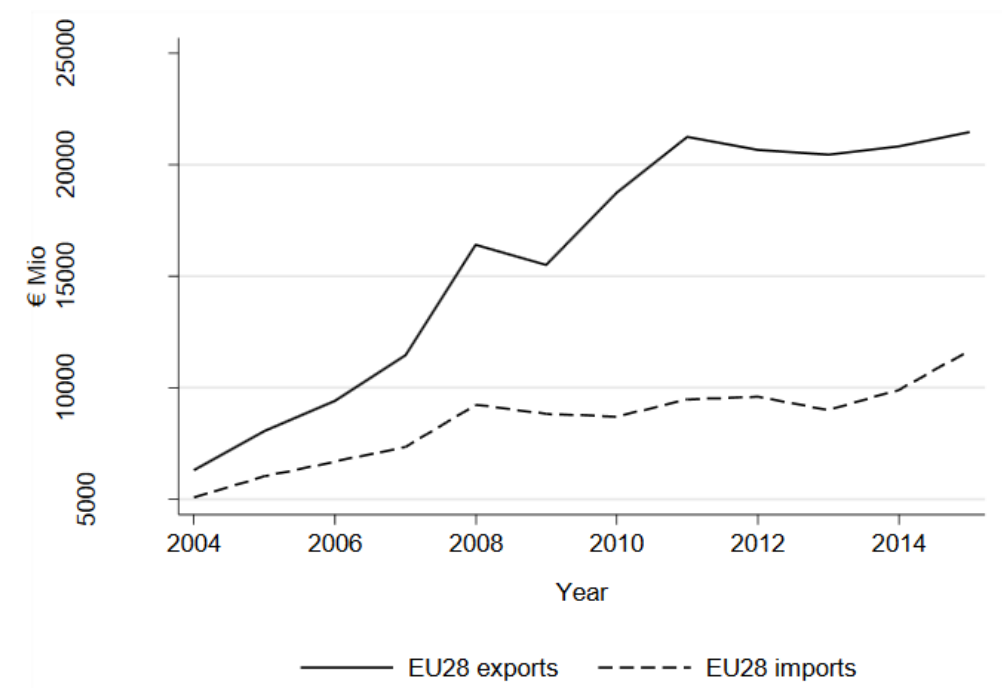


Draft, not to be quoted without permission of the author!

As for the service sector, both exports and imports to and from Mercosur increased substantially since 2004 as well (see Fig. 2), notably the shares for transport and travel that are considerably higher than for overall EU exports. Concerning EU-imports, business services account for $37 \%$, followed by transport (25\%) and travel (21\%). (LSE, 2018: 45).

After the EU-Mercosur deal had been signed, the EU Commission President Jean-Claude Juncker cheered, "A historic success". The internationally renowned president of the Institute of World Economics, Kiel, Gabriel Felbermayr, saw it even as a sign of the factual EU-power to shape global politics and to counter influential world leaders like Donald Trump who flatly deny climate change. Moreover, it would contribute to the rule of law in Latin-American countries with promising growth perspectives that however are liable to populism and protectionism and counted among the nations with the highest external tariffs worldwide (Pennekamp, 2019). Yet, critics condemned deficient ecological and sanitary standards as well as persistent non-tariff barriers to trade. The EU farm lobby complained about a sell-out of European interests in advantage of dominating multinationals.

Trade relations between the Mercosur and Africa were so far restricted to bilateral preferential trade agreements with a few African countries, South Africa, Egypt and Tunisia. However, the impact of the EU-Mercosur agreement on Africa has rarely been mentioned (Anskaityte, 2019). Therefore, I shall focus in the following on the possibly grave repercussions of the deal on Africa, taking three major product groups involved as an example, coffee, bananas and sugar.

\section{The impact of EU-Mercosur deal on African small-holders}

In the beginning, a general remark seems to be pertinent. When we consider possible repercussions of the EU-Mercosur deal on African producers we have always to bear in mind that 'the African' producer does not exist. Because of the large differences in production technics, as well as in economic and social resources of African export crop growers, the impact of the EU-Mercosur deal on different socio-economic strata differs radically as well.

In times of global capitalism, the international corporations and big producers will divest or shut-down their business if it is no longer profitable, even if thousands of their labourers will get unemployed, and invest their capital elsewhere. The small peasant grower, however, has no choice. Although the times are gone when his colonial master physically forced him into export crop production (see below), he is still compelled to obey the hidden laws of the capitalist market because he has to pay taxes, school fees, medical expenses etc. The 'African subsistence farmer' who could fall back on self-sufficient care for his own needs ceased to exist long ago, it is no option either, if it ever was. Therefore, the most likely consequence of his failure is that he will have to sell his property - in case he has any - and either to augment the ranks of unemployed urban dwellers in Africa's big cities or to look for his fortune in migrating to Europe.

\section{(2.1) EU-coffee imports: cut-throat competition}

Most coffee production is concentrated on the world's tropical belt where coffee had been introduced by the former colonial powers, keen to establish a profitable source of income for their treasuries. Therefore coffee planting was strongly encouraged, if not enforced, provided the plants did not grow already wild in the highlands as in Ethiopia, arguably the origin of coffee. Brazil, Vietnam and Colombia are the world's biggest coffee producers (s. map 2) and the new EU-Mercosur deal will open-up new distribution channels, notably for Brazil's coffee 
Draft, not to be quoted without permission of the author!

into the EU, most likely to the detriment of competing African producers that are mostly small-scale farmers.

Map 2: Major coffee-producing countries in the world

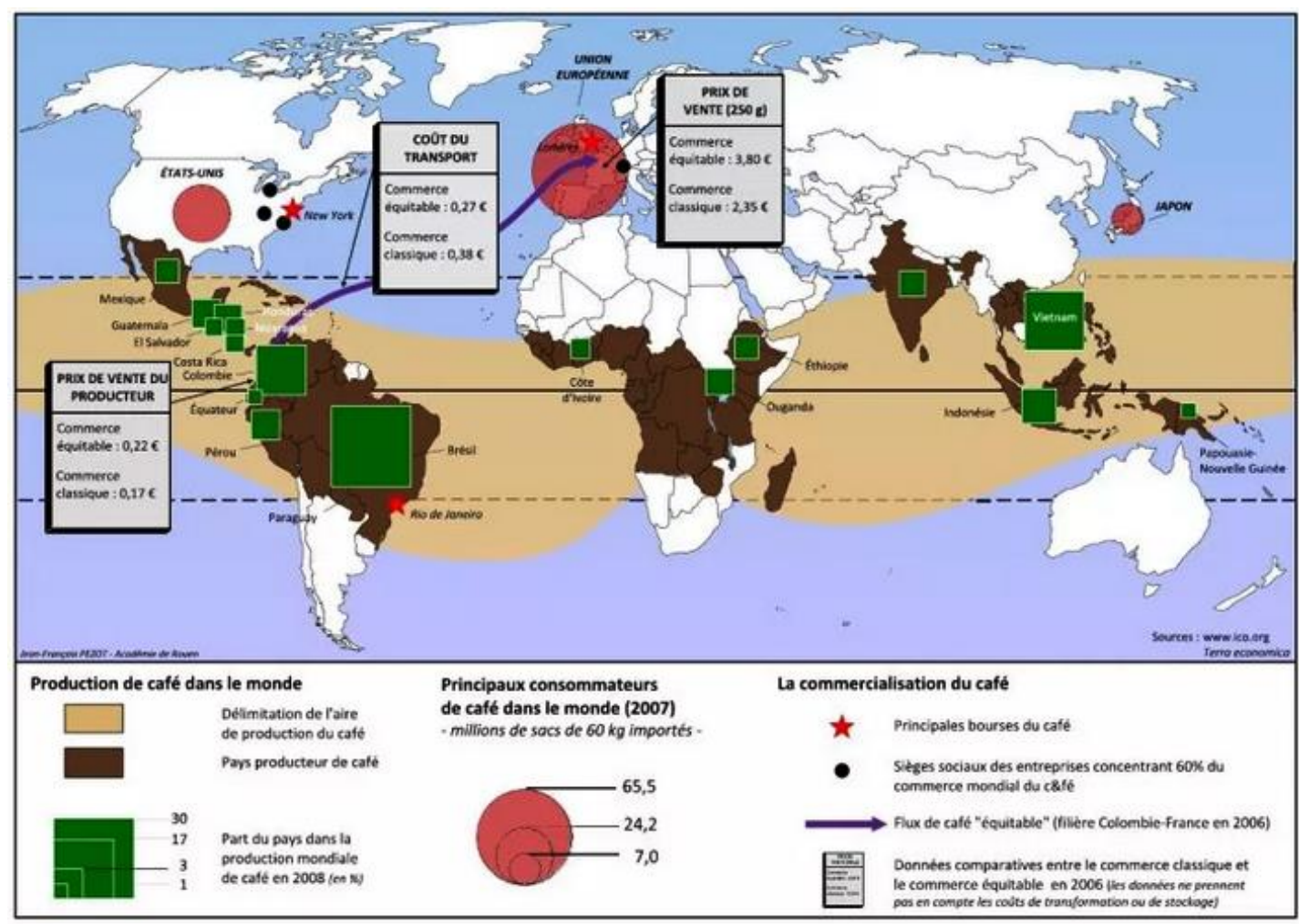

Source: Garcia, 2018

In Africa as well, the coffee was enforced on the population by the colonial powers. In Uganda, for example, coffee culture was compulsory for every free citizen. The export crop was the currency of exchange, as elsewhere in colonial Africa, like Nigeria, where the British introduced similar export crops and the poll-tax to force their subjects into the labour market to produce taxes for the coffers of their rulers (Kohnert, 1986). In their West Africa colonies the French introduced mainly Robusta, the most common African coffee brand of robust but inferior quality, which is easy to care for, has a greater crop yield and about double the amount of caffeine, compared with the brand Arabica which the British enforced on their subjects in their former colonies in East Africa.

Table 1: Major 7 African coffee-producing countries (2018)

\begin{tabular}{|l|r|c|}
\hline \multicolumn{1}{|c|}{ Country } & $60 \mathrm{~kg}$ bags & $\begin{array}{c}\% \text { export (1999) } \\
\text { of total production }\end{array}$ \\
\hline Ethiopia & $6,400,000$ & $47.4 \%$ \\
\hline Uganda & $4,800,000$ & $96.02 \%$ \\
\hline Côte d'Ivoire & $1,800,000$ & $61.05 \%$ \\
\hline Kenya & 833,000 & $77.7 \%$ \\
\hline Tanzania & 800,000 & $82.2 \%$ \\
\hline Cameroon & 570,000 & $88.8 \%$ \\
\hline Madagascar & 520,000 & $61.7 \%$ \\
\hline
\end{tabular}
Source: List of countries by coffee production. Wikipedia
FAfrica coffee-producing countries profiles (Annex 4), 1999


Draft, not to be quoted without permission of the author!

Since the past five decades, the market share of African coffee production in the world market fell significantly from $32 \%$ in the 1970 s to currently $10 \%$. This was due to intensified competition from Asian producers (Vietnam, Indonesia, India) as well as to a change in consumer preference, away from the Robusta brand the most widespread variety in Africa, towards Arabica (Macedo, 2019). Therefore, Ethiopia where some plants are naturally low in caffeine and where virtually exclusively Arabica is cultivated has become Africa's leading coffee grower, at a rate of 17 million sacks annually (Macedo, 2019). According to local saying the coffee plant originated in the country's highlands at Simado, Kaffa, Harar and Wollega, where the wild coffee is still collected by the villagers. Côte d'Ivoire, where mostly medium-quality Robusta beans are harvested which are mainly exported to France and Italy, is ranked second of all African producers. (Garcia, 2018).

Map 3: African coffee-producing countries, 2018

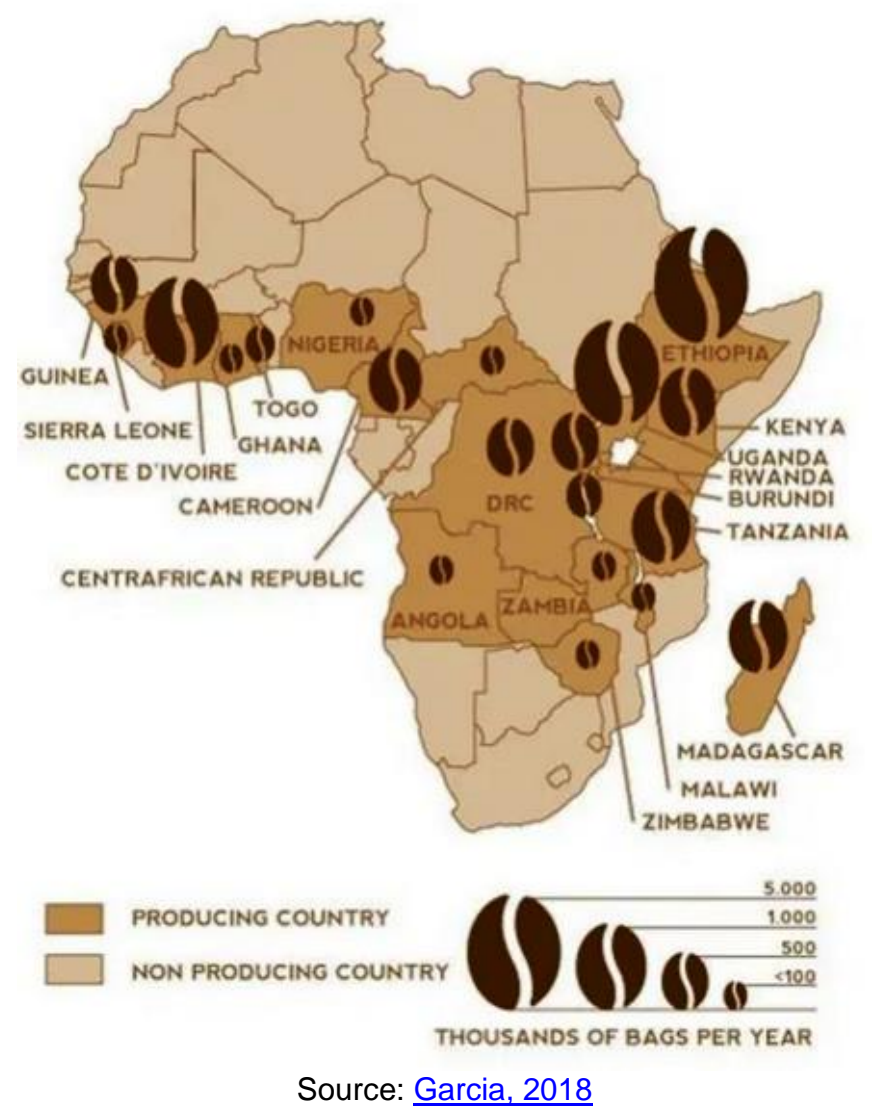

Apart from Ethiopia and Côte d'Ivoire, Uganda, Kenya, Rwanda and Tanzania counted among the major six African coffee growers. Ethiopia and Uganda together accounted alone for $62 \%$ of sub-Saharan Africa's coffee output. They too had suffered in recent years already under a world-wide decline of production although Arabica coffee has been hit mostly by the commodities' decline in comparison with the other 22 raw materials in the Bloomberg Commodity Index, dropping $24 \%$ in 2015, Robusta followed suit with $16 \%$ (Mungai, 2015). However, African producers were affected even more because of adverse weather conditions and since they had to compensate for their weak currencies. Now, they are likely to come under additional severe stress because of cut-throat competition not only with the Asian new-comers in the coffee market but also because of the increased competition with Brazil because of the EU-Mercosur deal that facilitated easier access to the EU-market.

Under these adverse conditions, the only solution to the African coffee crisis which the International Coffee Organization had to offer was, to increase Africa's own consumption, 
Draft, not to be quoted without permission of the author!

which up-to-date is significantly lower than in the rest of the world (see Grap 2; Macedo, 2019). Increased consumption would be also a pre-condition for creating local supply chains that could be used to create a value-added, for example by inventing special coffee brands and flavours, and thus upgrading the coffee's value-chains to deliver a more valuable product for the market (Macedo, 2019).

Graph 2: Share of Africa's coffee production \& consumption by country, 2015

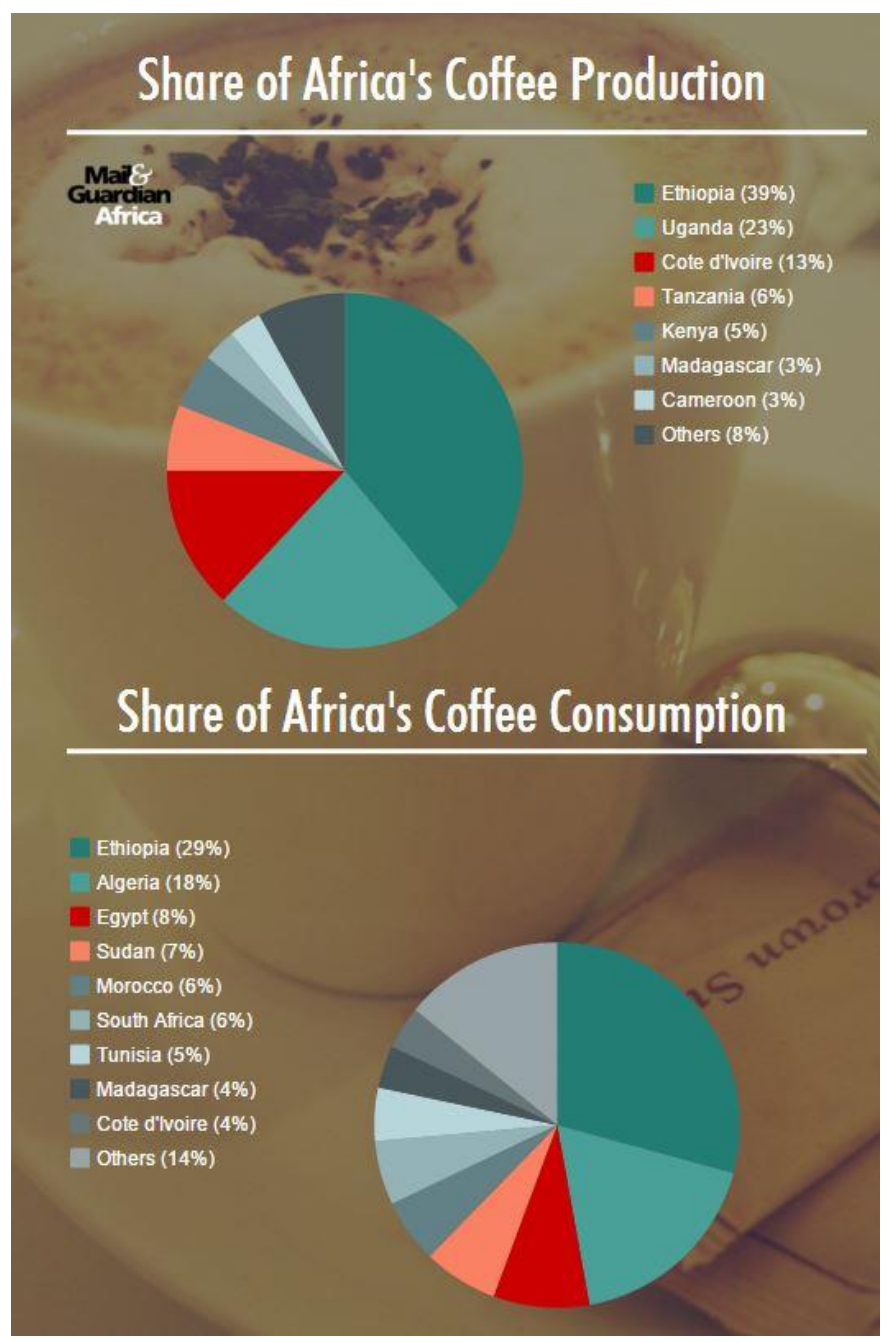

Source: $\underline{\text { Mungai, } 2015}$

(2.2) EU-banana imports in times of falling prices and tightening competition

Like coffee, bananas are an important staple crop in Africa, not only for export but also for local consumption. Production techniques vary considerably. Small-scale production for selfconsumption and the local market is labour intensive and requires only limited use of external inputs, whereas large-scale production for the export market on large plantations use sophisticated techniques and massive external input which results in an output up to six times higher than in small-scale production Since 1987 foreign companies like Del Monte, Dole and Chiquita began to take a leading role in the development of African banana for export, for example in Cameroon. Here and elsewhere in Africa, Banana growers produced for export under an arrangement whereby a few large operators specified the production technology and market the product internationally. However, in the Ivory Coast, most of the bananas for export were produced already in the early 2000s in 65 plantations on about 5,500 ha which employed about 20000 people (Arias et al, 2003). 
Draft, not to be quoted without permission of the author!

Whereas the majority of African growers produce still small-scale, labour intensive and with low technology and capital input, the situation in the Mercosur countries is completely different. Banana production in Brazil, for example, is mostly large-scale, if not industrial. Although Brazil ranks third on the list of the top Banana producers worldwide, it does not figure yet among the major exporters. In 2017 it produced 6.6 million tons of bananas. Besides, it harbours the headquarters of some of the most important multinationals in the banana production and export sector (Fresh-Plaza, 2019). Up to now, Brazil is the only Mercosur Banana exporter to the EU-market. Germany, on the other hand, which evidently does not produce bananas, does nevertheless figure among the top exporters, because it is not just a big consumer but also an entry point of bananas from overseas for re-export to countries like Belgium.

European producers complained that the EU-Mercosur deal threatens European banana growers. For example, the Spanish Association of Organizations of Producers of Platanos de Canarias (Asprocan) complained that Brazil could massively extend their exportation and flood the European market because it has the production potential, experience and infrastructure to do so. European producers could not compete on equal terms with Mercosur growers like Brazil and Argentina that do not observe the same environmental, labour, safety and social obligations like their European competitors (Fresh-Plaza, 2019). This comes at a time when banana growers suffer under falling prices and tightening competition anyway which further exacerbates the oversupply of the EU market. If already European growers are afraid that they could not compete with their Latin-American rivals, this applies even more for the majority of African banana growers.

Map 4: Banana exporting countries and export-value by country, 2013

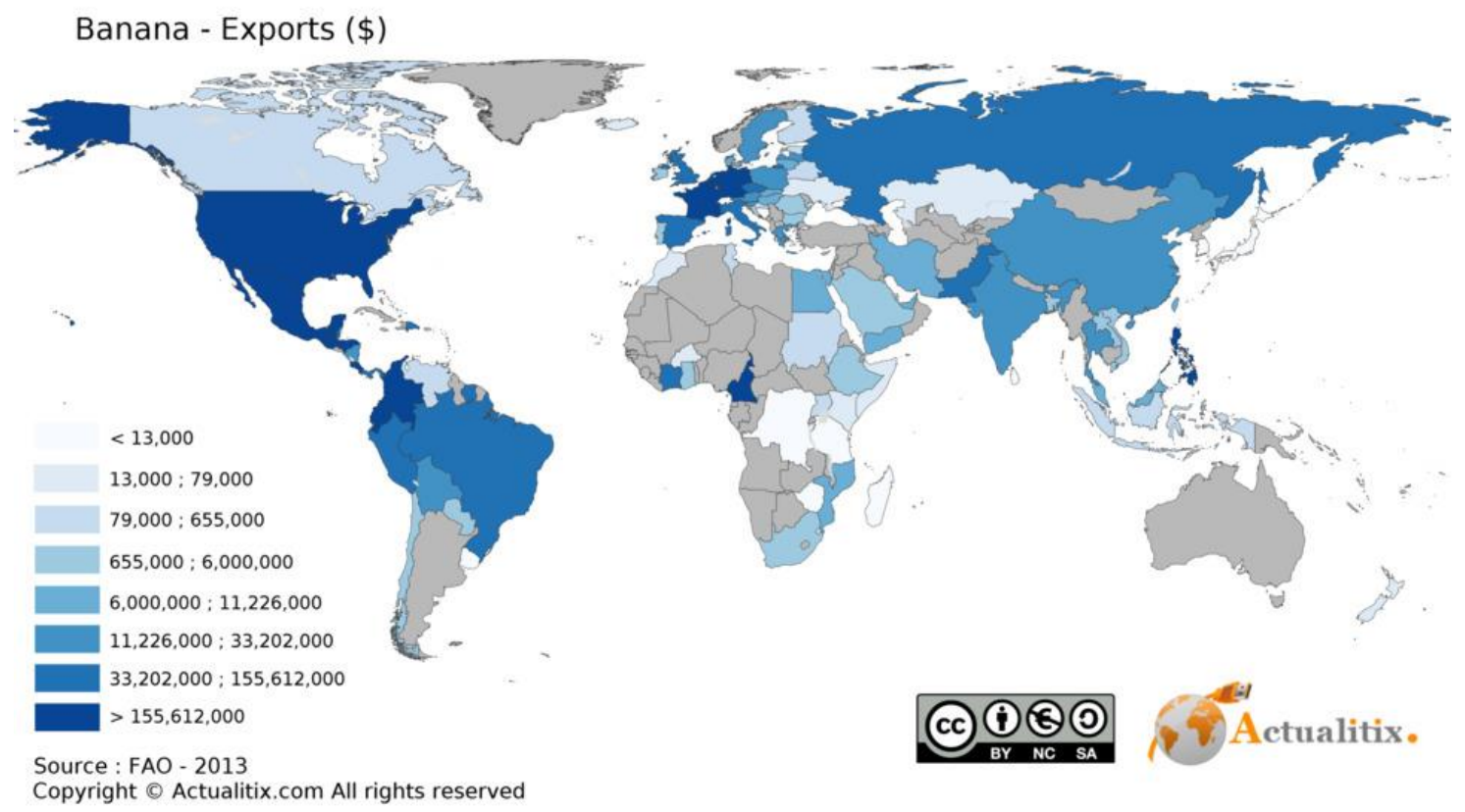

Source: Actualitix, interactive map, 2019; FAO, 2013

However, it apparently escaped the notice of the European banana lobby that it is not only European producers who are threatened by the unfair competition of powerful Latin American producers but African producers as well. Most African banana growers are smallscale producers. Because of their special relations to their former colonial powers their access to the European market has been regulated by successive EU-African agreements (Lomé Convention, 1975-1999; Cotonou Agreement since 2000, Everything but Arms (EBA) since 2001), most recently by the controversial Economic Partnership Agreements (EPAs), 
Draft, not to be quoted without permission of the author!

which apply for example for the emerging West African banana exporters like Ghana, Côte D'Ivoire and Cameroon, which have interim EPAs (Kohnert, 2015).

Map 5: African banana exporting countries and export-value by country, 2013

Banana - Exports (\$)

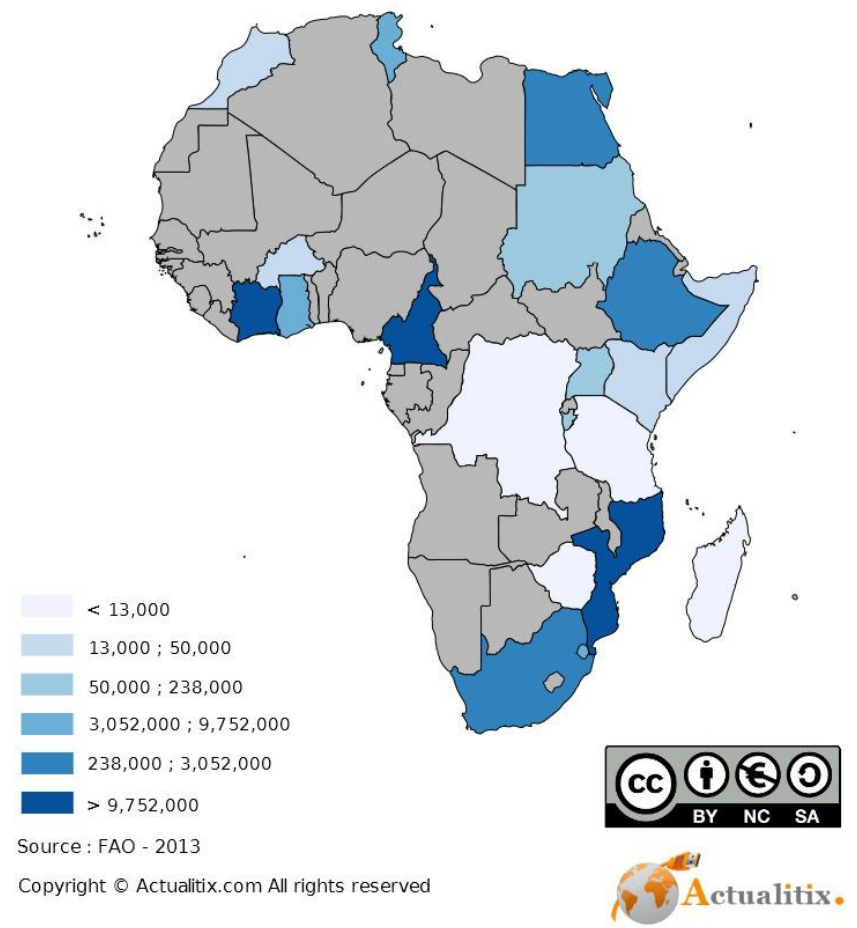

Source: Actualitix, interactive map, 2019; FAO, 2013

African banana producers still rely mainly on the European market, which often is a backbone of their weak economies, and to which they can export nearly tariff-free because of historic links with their former colonial powers. Still, In 2009, the EU reduced ACP out-ofquota banana tariffs from $€ 176$ per metric ton to $€ 114 €$. Also, Brussels contributed $€ 200 \mathrm{~m}$ to assist African, Caribbean and Pacific (ACP) producers to modernize their industry (Matthews, 2009: 232; here, and in the following I draw heavily on a study by Livingstone, 2019). Tellingly, the biggest banana corporations in Africa are still European-owned, such as France's Compagnie Fruitière.

Nevertheless, African growers associations are afraid that they could be put out of the market by cut-throat competition with Latin American producers under the new EU-Mercosur deal. The EU tried to disperse their fears by pointing to EU trade stabilization mechanisms that would allow for raising import tariffs in case of unfair competition (Livingstone, 2019). However, whereas the EU made extensive use of tariff-rate quotas (TRQ) with its major agro trade partners to protect the interests of European farmers, African governments on the contrary have not used TRQs to manage imports from the EU in sensitive agro-food products in their trade deals with the EU, apart from the EU-SADC EPA (EPA-Monitoring, 2019).

Yet, African growers remained sceptic because they consider these regulations rather as rhetoric because they allegedly have never been applied in the past. Moreover, African producers are well aware of the lasting 'dollar-dominance' of the banana-business. Not long ago, Latin American countries, driven by dominating US-American multinationals in the banana business, well-established in Latin America, like Chiquita, which was US-owned until 2015, instigated a 15 years long trade war against the European preference system for ACP countries (Livingstone, 2019). Lessons learned from that trade war sparked the renewed interest of the EU in Latin American banana producers. In 2012, the EU concluded 
Draft, not to be quoted without permission of the author!

subsequent trade agreements with six Central American countries, one year later also with Colombia and Peru, 2017 even with Ecuador, the top banana exporter worldwide. Consequently, its EU exports soared by $13.5 \%$ within one year (2016 to 2017) to reach 1.5 m metric tons (Livingston, 2019).

Apparently, African producers are no match to these giants: the Ivory Coast's banana exports into the EU amounted to merely 315,000 metric tons in 2017, Cameroon's to 270,000 tons and Ghana's to 70,000 tons (Livingstone, 2019). In case, the African banana industry could no longer compete in the expected cut-throat contest, about 80,000 Africans would be unemployed according to expert's forecasts (Livingstone, 2019).

Last, but not least, African producers, notably in Francophone Africa, are afraid that with Brexit the United Kingdom (UK) will abandon African sources in favour of cheaper suppliers from their former colonies in the Caribbean, which would cause additional stress, notably to Francophone African banana growers. But also Anglophone African countries are concerned. Up to now, for example, $90 \%$ of Ghana's banana exports that had increased from about 3,000 t per year in 2007 to over 70,000 $t$ in 2017, thus representing the third most important export crop behind cocoa and oil palm, went to the UK. Therefore, African banana producers created their own lobby group 'Afruibana' (headquarters in Douala, Cameroon, and Brussels) in 2017, to enhance their pressure on Brussels to mitigate against the dreaded negative impact of the EU-Mercosur deal (Livingstone, 2019).

\section{(2.3) Dwindling African sugar exports: collateral damage of EU-Mercosur deal}

Brazil and India are by far the biggest sugar producers worldwide with $37,300,000 \mathrm{t}$ and $26,605,000$ t respectively, according to the list of Sugar Producing Countries 2019 of the World Population Review. The biggest African producer is South Africa which produced with $2,192,000$ t the same quantity as Argentina, followed by Egypt with 2,114,000 t, Sudan $(762,000 \mathrm{t})$ and Swaziland $(707,000 \mathrm{t})$ that produced about the same amount like Japan $(729,000 \mathrm{t}$ ) (s. Table 2). Up to now, Brazil was allowed to export 180,000 t of sugar for refining into the EU. This will not be changed by the deal, however, a new duty-free quota of $10,000 \mathrm{t}$ was agreed only for Paraguay (EC, 2019d).

Table 2: African sugar producers, 2018 (in 1,000 metric tons)

\begin{tabular}{|c|c|c|c|c|c|c|c|c|}
\hline Rank & Country & $t$ & Rank & Country & $t$ & Rank & Country & $t$ \\
\hline 1 & South Africa & 2,192 & 12 & Malawi & 295 & 23 & Burkina Faso & 32 \\
\hline 2 & Egypt & 2,144 & 13 & Côte d'lvoire & 179 & 24 & Burundi & 25 \\
\hline 3 & Sudan & 762 & 14 & Cameroon & 150 & 25 & Guinea (C) & 24 \\
\hline 4 & Swaziland & 707 & 15 & Mali & 125 & 26 & Gabon & 23.8 \\
\hline 5 & Kenya & 593 & 16 & Senegal & 114 & 27 & Somalia & 23 \\
\hline 6 & Zimbabwe & 460 & 17 & Madagascar & 98 & 28 & Niger & 20 \\
\hline 7 & Zambia & 455 & 18 & DR Congo & 81 & 29 & Rwanda & 11 \\
\hline 8 & Mozambique & 432 & 19 & Congo (B) & 69 & 30 & C Afr.Rep. & 10.5 \\
\hline 9 & Ethiopia & 397 & 20 & Angola & 51 & 31 & Sierra Leone & 6 \\
\hline 10 & Uganda & 360 & 21 & Chad & 39 & 32 & Benin & 5 \\
\hline 11 & Tanzania & 333 & 22 & Nigeria & 37.5 & 33 & Liberia & 4.5 \\
\hline
\end{tabular}

Source: Sugar Producing Countries 2019, the World Population Review

The EU restructured its sugar regime in 2009 which encouraged a fierce competition of European sugar-beet production with sugar-cane production worldwide, especially in Africa. Moreover, the end of the EU quota regime in Europe in 2017, which had been introduced to protect the European sugar market, reinforced the ongoing tendency of the EU surplus 
Draft, not to be quoted without permission of the author!

production of refined sugar flooding the ACP countries by displacing ACP regional sugar exports (ACP sugar and Brexit, 2019; Graph 3). By the way, this thwarted European development cooperation that aided African sugar growers, e.g. in Mozambique, Tanzania and Malawi (EC, 2019b). Moreover, African sugar growers, notably those that do not belong to the African Commonwealth, are afraid that their exports to the UK which has been so far one of the major buyers of ACP / African sugar (see Graph 3), would be curtailed in the event of Brexit.

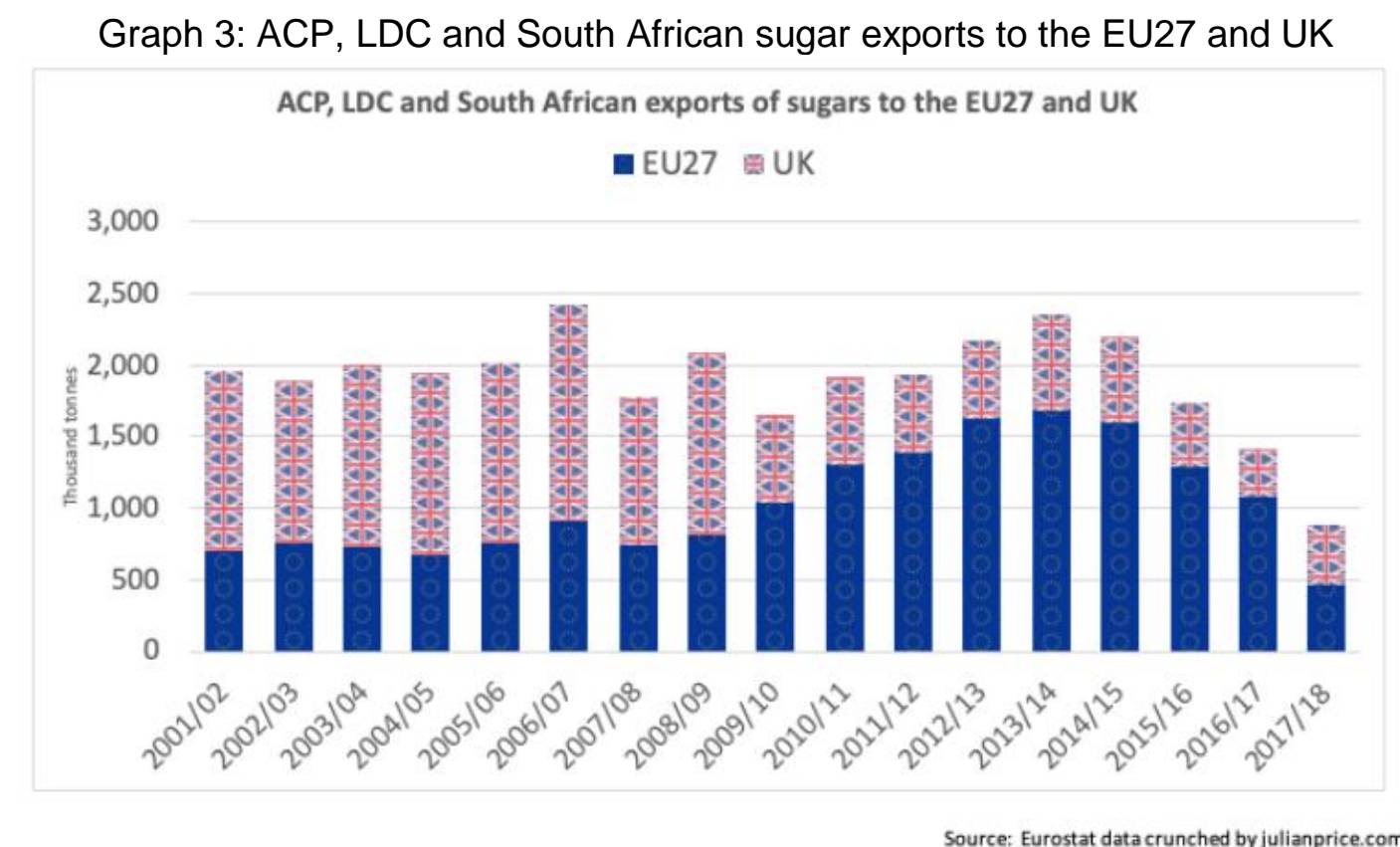

Source: ACP sugar and Brexit, 2019

Graph 4: EU refined sugar exports into ACP countries, displacing ACP/LDCs sugar exports, $2001-2019$

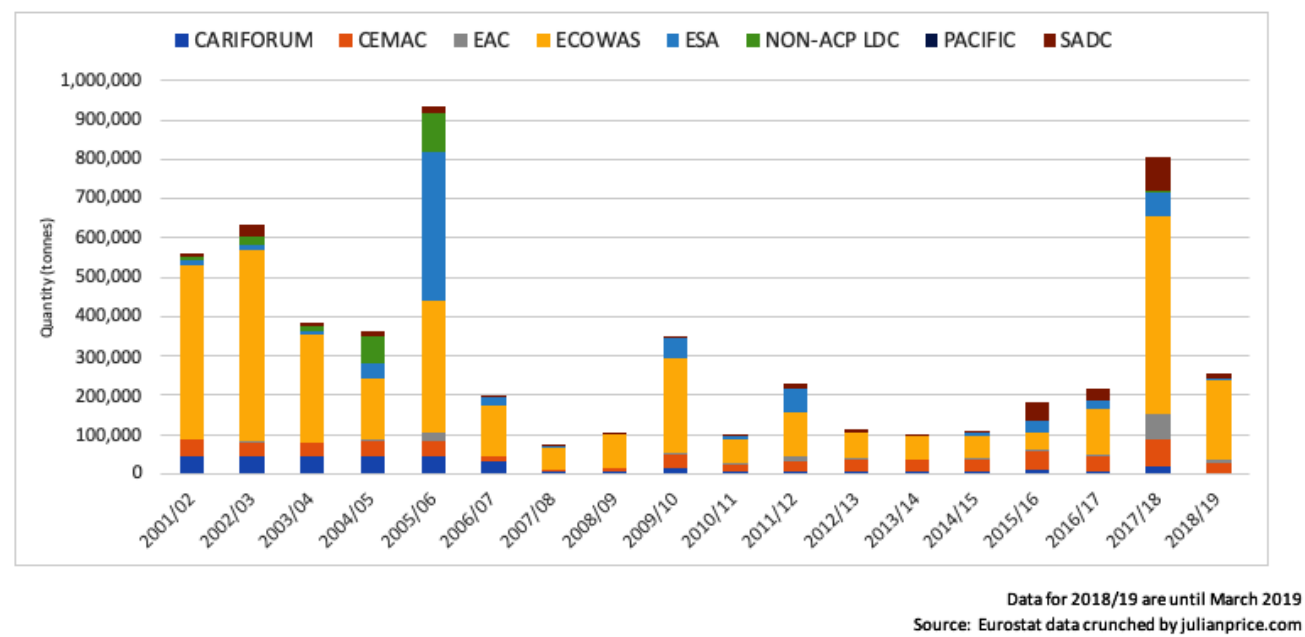

Source: ACP sugar and Brexit, 2019

Therefore, it was no surprise that the ACP was not amused about the EU-Mercosur deal. It complained that the EU apparently did not bother about the collateral damage done to its partners that had been traditionally a most important market for sugar from ACP and LDC 
Draft, not to be quoted without permission of the author!

countries $^{2}$. And this at a time of a depressed EU sugar market where prices reached a historic low in January 2019, suffering from the combined effects of oversupply and the current low world market prices, distorted by widespread subsidies (ACP-press, 2019). African sugar producers felt the more disappointed, if not deceived, as the EU apparently did not honour its commitment of partnership on equal terms under the Economic Partnership Agreements signed in good faith by many ACP countries: "It should be noted that increased access of sugar products from countries such as Brazil whose government supports its industry, is just as unfair to traditional suppliers of the EU as is the EU's continuing direct financial support for agricultural products such as sugar, dairy and beef' (ACP-press, 2019).

\section{(2.4) Collateral damages: Preference erosion for African smallholders}

Whereas European development cooperation with Africa underlines the importance of partnership on a level playing field and emphasizes the importance of extended value chains to enhance the value-added of African primary products and export crops already in the country of origin, the EU-Mercosur deal threatens to undermine this development policy by a creeping erosion of preferences granted since decades for its former colonies in Africa (here and in the following I rely heavily on Mari, 2019). As has been shown above, this effect will be especially pronounced for those African countries that export to the EU products that are heavily exported by Mercosur too (LSE, 2018: 41). Moreover, this applies especially for those products which are already processed, like Brazil's chocolate, roasted coffee and orange juice which have been subject to $10 \%$ to $20 \%$ import duty that would be cancelled as soon as the EU-Mercosur deal has been ratified (Marie, 2019). Furthermore, Mercosur members like Brazil will even have a competitive edge over their African rivals because of the tricky question of rules of origin for components of processed goods like chocolate, as Brazil, produces both cocoa and sugar within its own boundaries. Investors who were lured into investing in value-added chains in Africa by special support programs, like the German Marshall Plan with Africa, the G20 Compact with Africa or the US African Growth and Opportunity Act (AGOA) will think twice whether they should continue to invest in Africa, if cocoa butter, chocolate or pineapple- and orange juice from West African countries like Benin or Togo profit no longer from tariff exemption compared with Brazil, as Francisco Mari (2019) from the German NGO 'Bread for the World' explained. In his blog on the EUMercosur deal he continued with other telling examples to highlight this preference erosion concerning: "the export of canned fish from Côte d'Ivoire", Kenyan green beans or South African citrus fruits. Also, the expansion of quota imports into the EU for beef and poultry will directly hit Namibia's beef exports and, indirectly, poultry will again be flooding African markets in the form of hundreds of thousands of tons of chicken pieces from Brazil'. The EU will limit the new 100,000 t import quota for poultry from South America to imports of chicken fillet. This again creates three times the amount of 'remnants' that Brazil, as before and just like the EU and the US is shipping to Africa. Nice views for the African breeders." (Mari, 2019; transl. D.K.).

\footnotetext{
${ }^{2}$ „ACP and LDC countries note with great concern reports that 180,000 metric tonnes of tariff-free access for sugar is included in the EU/Mercosur trade agreement under the existing 334,054 tonnes CXL quota at $98 € / \mathrm{t}$ for Brazil, in other words, the first 180,000 tonnes of access would be duty-free each year, and also an additional 10,000 tonnes duty-free quota for Paraguay. These new concessions would be in addition to the Brazil CXL quota of 78,000 tonnes at $11 € / \mathrm{t}$ duty and the 289,977 tonnes CXL Erga Omnes quota at $98 € / \mathrm{t}$ which mostly tends to be supplied by Mercosur countries." (ACP-press, 2019).

${ }^{3}$ other major producers of canned Tuna in Sub-Sahara Africa beside Ivory Coast (1,100,000 mt; direct employment 3,000, in 2009) were Ghana (direct employment, 1,200), Madagascar (direct employment: 1,500), Mauritius (direct employment, 1,700), Senegal (direct employment, 1,340) and the Seychelles (direct employment, 2,300). (Source: FFA, 2010:235; footnote, D.K.).

${ }^{4}$ This the more so, because EU poultry exports to Sub-Sahara Africa $(1,579,891 \mathrm{t}$ in 2018$)$ are rising as well again after the export shock of the decision of South Africa in December 2016 to impose SPS (sanitary and phytosanitary) based import restrictions on poultry meat imports from certain EU member states where Avian Influenza outbreaks had occurred (EPA-monitoring, 2019a).
} 
Draft, not to be quoted without permission of the author!

\section{Conclusion}

The EU-Mercosur deal - if applied in its present form - is threatening not only European farmers but also keeps hitherto widely ignored risks for African smallholders and export crop producers as shown above. However, it provides also important lessons to be learned for future negotiations with the EU. This applies especially to the likely (re-)negotiation of EPAs both with the EU27 and the UK in the case of Brexit. But it concerns also the follow-up of the Joint Africa-EU Strategy (JAES), adopted at the second EU-Africa Summit in Lisbon in 2007, and the eventual prolongation of the Cotonou agreement, ending 2020, after 20 years run time or a follow-up accord which has been discussed since 2017.

African governments will be well advised to study carefully the EU-Mercosur accord, notably concerning vital agricultural exports and value-added chains. To better protect their infant industries and to promote inclusive growth, they might be inclined to introduce in future a similar quota-based 'careful market opening' vis à vis the EU as their Mercosur competitors within the framework of the most favoured nation (MFN) clause of the WTO (EPA-Monitoring, 2019). Furthermore, African countries like Namibia would now be in a better position to defend their long-standing demand for a 'regionalization' of sanitary and phytosanitary (SPS) measures for their beef and lamb exports. In recent years the EU had used its refusal of such a 'regionalization' to exclude Namibian peasant farmers keeping cattle and sheep on communal land from high-value export supply chains (EPA-Monitoring, 2019). Finally, African governments should think twice whether they should continue to accept 'tariff standstill' clauses in the EPAs that permit a tariff standstill on all products and would expose sensitive agro-food sectors to continued growth in EU exports, for example the EU poultry exports to Africa which are again on a rise (EPA-Monitoring, 2019; 2019a).

All in all, the EU-Mercosur deal provides not only risks but also openings to African countries. In times of increasing influence of new global players like China and India in African trade relations, they could use the lessons learned from the EU-Mercosur deal to retrieve their seesaw policy, already used successfully in times of the cold war. Thus, for example, they would be able to enforce re-negotiations on a level playing field with the EU and the UK in the upcoming consultations on the re-negotiation of the EPAs and similar trade and development agreements with Brussels and London in the case of Brexit. 
Draft, not to be quoted without permission of the author!

\section{References}

ACP-press (2019): ACP Group's response to recently concluded Free Trade Agreement between EU and Mercosur. Brussels: ACP-press, 4 Jul 2019

AEO (2018): African Economic Outlook - 2018. Abidjan: African Development Bank (AfdB)

Anskaityte, Indre (2019): Mercosur Agreement: the EU Turned a Blind Eye to the Concerning Situation in Brazil. Slow Food Europe, 01 July 2019 (n. p.)

Arias, Pedro et al. (2003): The World Banana Economy, 1985-2002. Rome: Food and Agricultural Organisation (FAO))

Bertolini, Micol (2019): UE-MERCOSUR : Un accord historique mais controversé. Brussels: thenewfederalist.eu, The New Federalist, magazine of the Young European Federalists (JEFEurope), 16 July 2019

Bonse, Eric (2019): EU-Mercosur-Pakt - Der Widerstand erreicht Brüssel. Berlin: Die Tageszeitung (taz), 30 August 2019

Brunsden, Jim \& Andres Schipani \& Bryan Harris \& Benedict Mander (2019): EU-Mercosur trade deal: what it all means. Brussels: Financial Times, 30 June 2019

EC (2019) : EU und Mercosur-Staaten einigen sich auf umfassendes Freihandelsabkommen. Brüssel: European Commission

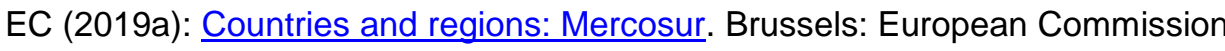

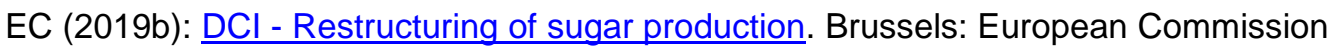

EC (2019c): EU-Mercosur trade agreement - Building bridges for trade and sustainable development Key Facts. Brussels, European Commission, 2 August 2019

EC (2019d): EU-Mercosur trade agreement - Creating opportunities while respecting the interests $f$ European farmers. Brussels, European Commission, 2 August 2019

EP (2019): Citrus fruit in the EU-Mercosur agreement. Brussels: European Parliament

EIU (2019): Mercosur-EU deal agreed at last. London: Economist Intelligence Unit (EIU), 2 July 2019

EPA-Monitoring (2019): The EU-Mercosur agreement Part 1: Overview and lessons for the ACP Brussels: epamonitoring.net, 22 August 2019

EPA-Monitoring (2019a): EU Poultry exports to Sub-Saharan Africa once again on the rise. Brussels, epamonitoring.net, June 20, 2019

FFA (2010): The global tuna market. Industry dynamics. Part 1b. Canned tuna processors. Honiara, Solomon Islands: Pacific Islands Forum Fisheries Agency (FFA), 2010: 235

Fresh-Plaza (2019): Asprocan claims agreement with Mercosur will increase risk of banana oversupply. Tholen (Netherlands): Fresh Plaza, 10 July 2019

Fritz, Thomas (2019): Das EU-Mercosur-Abkommen auf dem Prüfstand. Soziale, ökologische und menschenrechtliche Folgen. Aachen: Misereor

Garcia, Thomas (2018): Coffee-producing countries: Africa. Coffee Geek, online

Khan, Mehreen \& Jim Brunsden ( 2019): Dutch minister defends Mercosur deal from green critics. London. Financial Times, 8 July 2019

Kohnert, Dirk (2018): More equitable British post-Brexit Africa relations: doomed to fail?, Africa Spectrum, vol. 53., No. 2, pp. 119-130 
Draft, not to be quoted without permission of the author!

Kohnert, Dirk (2018a): Britain, Brexit and Africa. ROAPE-blog, Review of African Political Economy, published on 31 October 2018

Kohnert, Dirk (2015): Horse Trading on EU-African Economic Partnership Agreements. Review of African Political Economy, 41 (2015) 143: 141-147

Kohnert, Dirk (2005): Monetary Unions - Dominated by the North? The CFA-Zone and the CMA - On the relevance of rational economic reasoning under African conditions. In: Fritz, Barbara / Metzger, Martina (eds.)(2005): New Issues in Regional Monetary Coordination - Understanding North-South and South-South Arrangements, Palgrave Macmillan, Houndmills, Basingstoke, Hampshire, pp. 177-187

Kohnert, Dirk (1994): Die Krise der Communauté Française Africaine [The crisis of the French African Community, CFA], Internationale Politik und Gesellschaft, 1994.4:385 - 396

Kohnert, Dirk (1986): "The transformation of rural labour systems in colonial and post-colonial northern Nigeria", Journal of Peasant Studies, 13 (1986) 4: 258-271

Langan, Mark (2016); Brexit and Trade Ties between Europe and Commonwealth States in SubSaharan Africa: Opportunities for Pro-poor Growth or a Further Entrenchment of North-South Inequalities?, The Round Table, 105:5, 477-487, DOI: 10.1080/00358533.2016.1233758

Livingstone, Emmet (2019): EU trade outlook alarms Afric's banana exporters. African exporters see Brexit and EU-Latin American trade as existential threats. Brussels: Politico (news organization), 19 April 2019

LSE (2018): Sustainability impact assessment in support of association agreement negotiations between the European Union and Mercosur. Final Inception Report. London: LSE Enterprise Limited, London School of Economics and Political Science. Inception Report, 24 January 2018.

Macedo, Emanuel de (2019): Brazilian leadership inspires African coffee growers. Atlantic-online.com, 17 June 2019

Margolis, Mac (2019): Latin America and Free Trade Score a Win - A trade pact between the European Union and Mercosur opens doors on both sides of the Atlantic. Bloomberg.com, 8.July 2019

Marí, Francisco (2019): Mercosur-Abkommen schadet BäuerInnen weltweit. Stuttgart: Brot für die Welt (BfDW), 1 July 2019

Matthews, Alan (2015): The EU has finally agreed to eliminate export subsidies...three cheers! capreform.eu/

Matthews, Alan (2009) EPAs and the demise of the commodity protocols. In: Faber, Gerrit \& Jan Orbie (eds): Beyond market access for economic development: EU-Africa relations in transition. London: Routledge, 2009: 217-241

Maxwell, Maura (2019): EU and Mercosur sign historic trade deal - Agreement welcomed by South American fruit exporters, but EU producers react with dismay. London: Fruitnet.com, 1st July 2019

Mbembe, Achille (2010): Sortir de la grande nuit. Essai sur l'Afrique décolonisée. Paris: La Découverte

Medico International (2019): EU-MERCOSUR - Abkommen: Brasilien - Rekolonisierung. Frankfurt a.M.

Mungai, Christine (2015): Which African countries produce the most coffee? Cologny/Geneva: World Economic Forum, 22 Oct 2015

Pennekamp, Johannes (2019): Felbermayr zu Mercosur-Deal : „Das Abkommen bringt jedem Deutschen 60 Euro pro Kopf“. Frankfurt M.: Frankfurter Allegemeine Zeitung (faz), 30 June 2019 
Draft, not to be quoted without permission of the author!

Schwarzbauer, Annette \& Johannes Hügel (2019): Freihandelsabkommen EU-MERCOSUR „Südbrücke“ im Atlantik. Bonn: Konrad Adenauer Stiftung, Länderbericht, Regionalteam Lateinamerika, 10 July 2019

Stollreiter, Susanne (2019): Der Deal mit dem Deal. Das Handelsabkommen zwischen der EU und den Mercosur-Ländern steht in der Kritik - und nun stellt sich Frankreich quer. Bonn: IPG Internationale Politik und Gesellschaft, 3 July 2019 
Draft, not to be quoted without permission of the author!

Résumé : L'accord de 2019 entre l'UE et le Mercosur a été qualifié de jalon dans les accords de libre-échange dans le monde entier à une époque de protectionnisme et de nationalisme grandissants. Les critiques ont condamné les normes écologiques et sanitaires déficientes, ainsi que les obstacles non-tarifaires persistants au commerce. Le lobby agricole de l'UE s'est plaint de la vente d'intérêts européens au profit de multinationales dominantes. Cependant, les répercussions fatales de l'accord sur l'Afrique ont rarement été mentionnées. Ils incluent une concurrence acharnée et un partenariat asymétrique au détriment des pauvres en Afrique. Compte tenu de l'impact destructeur supplémentaire de la crise du Brexit, les gouvernements africains devraient utiliser leur pouvoir de négociation accru vis-à-vis de l'UE27 et du RoyaumeUni, en période de durcissement de la concurrence concernant le commerce africaine de l'UE avec des nouveaux acteurs mondiaux tels que la Chine et l'Inde, pour imposer des renégociations des APEs sur un pied d'égalité.

Zusammenfassung : Das Abkommen zwischen der EU und dem Mercosur von 2019 wurde als Meilenstein für weltweite Freihandelsabkommen in Zeiten wachsenden Protektionismus und Nationalismus eingeläutet. Kritiker bemängelten unzureichende Umwelt- und Hygienestandards sowie anhaltende nichttarifäre Handelshemmnisse. Die EU-Agrarlobby beschwerte sich außerdem über einen Ausverkauf europäischer Interessen zugunsten dominierender multinationaler Unternehmen. Die fatalen Auswirkungen des Abkommens auf Afrika wurden jedoch selten erwähnt. Dazu gehören ein zunehmender Verdrängungswettbewerb und eine asymmetrische Partnerschaft zum Nachteil der afrikanischen Armen. Angesichts der zusätzlichen destruktiven Auswirkungen der Brexit-Krise sollten die afrikanischen Regierungen, in Zeiten zunehmenden Wettbewerbs im Afrikahandel der EU mit neuen globalen Akteuren wie China und Indien, ihre verstärkte Verhandlungsmacht gegenüber der EU27 und Großbritannien einsetzen, um Neuverhandlungen der Wirtschaftlichen Partnerschaftsabkommen auf Augenhöhe durchzusetzen. 